\title{
Planting Medium Effects on Forced Swaziland- and Dutch-grown Hippeastrum Hybrids
}

\author{
A.A. De Hertogh ${ }^{1}$ and M. Tilley ${ }^{2}$ \\ Department of Horticultural Science, North Carolina State University, \\ Raleigh, NC 27695- 7609
}

Additional index words. Amaryllis hybrids, root growth, flowering

\begin{abstract}
The Swaziland-grown Hippeastrum bulbs 'Summertime' and 'Sun Dance' reached the market and flowering stages of development in fewer days than the Dutchgrown bulbs 'Apple Blossom' and 'Red Lion'. 'Sun Dance' was the quickest flower and 'Red Lion' the slowest. The effects of the planting medium on days to market and flowering were variable and no medium appeared to be the best for this criterion. 'Summertime' and 'Red Lion' produced longer leaves at flowering than 'Apple Blossom' and 'Sun Dance'. Three media that led to the production of the longest leaves, a desirable trait, were: Sunshine no. 4, Fafard 3-B, and Sunshine Post-Harvest. 'Apple Blossom' was the tallest cultivar followed by 'Sun Dance', 'Red Lion', and 'Summertime'. Effects of the planting medium on total plant height were variable. The overall plant quality ratings for use as potted plants ranged from 3.4 to 3.8 out of 4 for 'Summertime', 'Sun Dance', and 'Red Lion'. 'Apple Blossom' was rated 3.0 because it was tall and had short leaves. It would be suitable as a cut flower. Regardless of the planting medium used, 'Apple Blossom' lost the greatest amount of old basal roots. Consequently, it produced many new basal roots. The planting medium had variable effects on old and new basal roots and secondary root growth, depending on the cultivar. Based on all the flowering criteria and the rooting responses, the best media for all cultivars as potted plants were Fafard 3-B and Sunshine Mix no. 4. Fafard no. 2 was best for cut-flower usage since it produced taller plants with a good root system.
\end{abstract}

Hippeastrum spp. are indigenous to Central and South America (Liberty Hyde Bailey Hortorium, 1976). In the floriculture industry, however, they are generally known as Amaryllis (Vijverberg, 1980, 1981). Hippeastrum have been extensively bred and grown in The Netherlands and South Africa. This has led to development of many cultivars (Zandbergen, 1980). For use in North America (De Hertogh, 1989), bulbs grown in the above countries must be washed free of soil immediately after harvest to comply with plant quarantine regulations. The bulbs subsequently are stored for several weeks and then transported for 2 to 5 weeks. As a result of these handling procedures, the basal roots

Received for publication 6 Dec. 1990. We acknowledge the donation of the bulbs by Swazibulb (Pty) Limited, Nhlangano, Swaziland, and The Dutch Bulb Exporters Assn., Hillegom, The Netherlands. The latter organization also provided financial support for this research. We acknowledge the donations of the various planting media by: ASB-Greenworld, Inc., Farfard, Inc., W.R. Grace and Co., and Fison Western Corp. Lastly, we want to thank W. Swallow and L. Lehman for their assistance with the statistical analyses and P. Breed and A. Rutte for technical assistance. The use of trade names in this publication does not imply endorsement by the North Carolina Agricultural Research Service of the products named, nor criticism of similar ones not mentioned. The cost of publishing this paper was defrayed in part by the payment of page charges. Under postal regulations, this paper therefore must be hereby marked advertisement solely to indicate this fact.

'Professor.

${ }^{2}$ Agricultural Research Technician. of the bulbs may dry out. To produce quality plants, a new viable root system must be established as quickly as possible after planting. One of the major factors that affect root development is the planting medium (Genders, 1973). Also, it is known with tulips that aeration is an important factor for root development (De Haan and Van der Valk, 1971; Van der Valk, 1971; Wiersum, 1971). Thus, the objective of this study was to evaluate the effects of seven commercially available planting media and two formulated at our laboratory on the forcing and rooting

Table 1. Description of planting media used.

\begin{tabular}{|c|c|c|}
\hline \multicolumn{2}{|c|}{ Plant media } & \multirow[b]{2}{*}{ Basic constituents } \\
\hline Name & Abbrev. & \\
\hline NCSU Bark & $\mathrm{NCB}$ & $\begin{array}{l}\text { Equal volumes shredded pine bark, sand, sphagnum peat, sandy } \\
\text { loam soil plus dolomitic }\left(5.23 \mathrm{~kg}-\mathrm{m}-{ }^{-“}\right) \text { and hydrated lime } \\
\left(1.31 \mathrm{~kg} \cdot \mathrm{m}^{-3}\right) \text { mixed, then sterilized. }\end{array}$ \\
\hline NCSU Soil & NCS & $\begin{array}{l}2 \text { Sandy loam : } 1 \text { sand : } 1 \text { sphagnum peat (by volume) plus } \\
\text { dolomitic }\left(5.23 \mathrm{~kg} \cdot \mathrm{m}^{-3}\right) \text { and hydrated lime }\left(1.31 \mathrm{~kg} \cdot \mathrm{m}^{-3}\right) \\
\text { mixed, then sterilized. }\end{array}$ \\
\hline $\begin{array}{l}\text { ASB Grower Mix } \\
\text { VPW-30 }\end{array}$ & ASB & $\begin{array}{l}\text { Sphagnum peat, perlite, vermiculite, nutrient charge, starter } \\
\text { fertilizer, superphosphate, trace elements, wetting agent, and } \\
\text { Bentonite clay. }\end{array}$ \\
\hline Fafard no. 2 & $\mathrm{~F} 2$ & $\begin{array}{l}\text { Sphagnum peat, perlite, vermiculite, nutrient charge, starter } \\
\text { fertilizer, superphosphate, trace elements, and wetting agent. }\end{array}$ \\
\hline Fafard no. 3-B & F3B & $\begin{array}{l}\text { Bark, sphagnum peat, perlite, vermiculite, nutrient charge, starter } \\
\text { fertilizer, superphosphate, trace elements, and wetting agent. }\end{array}$ \\
\hline Metro Mix 350 & M350 & $\begin{array}{l}\text { Pine bark ash, sphagnum peat, sand, vermiculite, nutrient charge, } \\
\text { starter fertilizer, trace elements, and wetting agent. }\end{array}$ \\
\hline Metro Mix 360 & M360 & $\begin{array}{l}\text { Pine bark ash, sphagnum peat, sand, vermiculite, nutrient charge, } \\
\text { starter fertilizer, trace elements, and wetting agent. }\end{array}$ \\
\hline Sunshine Mix no. 4 & SM4 & $\begin{array}{l}\text { Sphagnum peat, perlite, limestone, nutrient charge, trace ele- } \\
\text { ments, and wetting agent. }\end{array}$ \\
\hline $\begin{array}{l}\text { Sunshine Post- } \\
\text { Harvest Mix }\end{array}$ & SPH & $\begin{array}{l}\text { Sphagnum peat, perlite, nutrient charge, trace elements, wet- } \\
\text { ting agent, Bentonite clay, and superabsorbent polymers. }\end{array}$ \\
\hline
\end{tabular}

characteristics of Hippeastrum (Amaryllis).

A preliminary trial, conducted in 198889 , demonstrated that there were considerable differences in response to planting media. Thus, a large trial was conducted during the 1989-90 forcing season. From each production source, 135 bulbs (28 to $30 \mathrm{~cm}$ in circumference) of each cultivar were obtained. Bulbs ('Summertime' and 'Sun Dance') from Swaziland were shipped on 24 July 1989, arrived at Raleigh, N.C., on 17 Aug., and were stored in cardboard shipping cartons at 9C until planted. Bulbs ('Apple Blossom' and 'Red Lion') from The Netherlands were air-freighted in cardboard boxes on 3 Nov. 1989, arrived on 7 Nov., and were stored at $13 \mathrm{C}$. The difference in the preplanting storage temperature used (Vijverberg, $1980,1981)$ was due to the presence of emerged leaves in the Swaziland-grown bulbs.

Planting dates were 10 Oct. and 16 Nov. for the Swaziland- and Dutch-grown bulbs, respectively. Bulbs were planted with onethird of the bulb above the surface of the medium in $15-\mathrm{cm}$ diameter, standard depth (1.8 liter) plastic pots. Fifteen pots were used per planting medium and cultivar. After a thorough initial watering, all bulbs were blocked by cultivar on the same heating mat. The planting media (Table 1) were randomized per cultivar. This was necessary because the growth varied for each cultivar and medium, and they had to be watered only as needed. All pots were placed on electrically controlled heating mats that maintained the medium at $23 \pm 1 \mathrm{C}$. None of the plants were fertilized and they were grown under prevailing light conditions. Data were analyzed as a randomized complete block with each cultivar serving as a block. Means separation was by Duncan's new multiple range test. Data for cultivars from the same production source were combined when the interaction with the planting medium treatments was nonsignificant.

Marketing stage was recorded when the first floral stalk had reached $30 \mathrm{~cm}$ above 


\begin{tabular}{|c|c|c|c|c|c|c|c|c|c|c|c|c|c|c|}
\hline \multirow{4}{*}{$\begin{array}{l}\text { Planting } \\
\text { medium }\end{array}$} & \multicolumn{14}{|c|}{ Fresh wt/bulb $(\mathrm{g})$} \\
\hline & \multicolumn{8}{|c|}{ Basal roots } & \multirow{2}{*}{\multicolumn{3}{|c|}{ Secondary roots }} & \multirow{2}{*}{\multicolumn{3}{|c|}{ Total roots }} \\
\hline & \multicolumn{4}{|c|}{ Old } & \multicolumn{4}{|c|}{ New } & & & & & & \\
\hline & $S$ & $\mathrm{SD}$ & $\mathrm{AB}$ & $\mathrm{RL}$ & $S$ & SD & $\mathrm{AB}$ & $\mathrm{RL}$ & $S+S D$ & $\overline{A B}$ & RL & $S+S D$ & $\mathrm{AB}$ & RL \\
\hline$\overline{\mathrm{NCB}}$ & 34.3 & 41.3 & $5.3 \mathrm{ab}$ & 17.9 & $2.3 \mathrm{c}$ & $1.1 \mathrm{abc}$ & $12.0 \mathrm{~b}$ & $4.2 b c$ & $8.3 \mathrm{c}$ & $3.3 \mathrm{~b}$ & $2.6 \mathrm{~d}$ & $47.7 c$ & $20.5 b c$ & $24.7 \mathrm{c}$ \\
\hline NCS & 38.4 & 43.6 & $6.2 \mathrm{ab}$ & 20.8 & $3.3 \mathrm{bc}$ & $0.3 \mathrm{c}$ & $6.4 \mathrm{c}$ & $2.2 \mathrm{~cd}$ & $9.2 \mathrm{c}$ & $3.3 \mathrm{~b}$ & $5.1 \mathrm{~cd}$ & $51.9 \mathrm{bc}$ & $15.9 \mathrm{c}$ & $28.0 \mathrm{abc}$ \\
\hline ASB & 40.6 & 43.0 & $6.2 \mathrm{ab}$ & 19.7 & $2.8 \mathrm{bc}$ & $2.5 \mathrm{a}$ & $12.9 \mathrm{ab}$ & $1.3 \mathrm{~d}$ & $9.9 c$ & $4.1 \mathrm{~b}$ & $9.9 \mathrm{a}$ & $54.3 \mathrm{abc}$ & $23.2 \mathrm{bc}$ & $31.0 \mathrm{abc}$ \\
\hline $\mathrm{F} 2$ & 38.9 & 39.2 & $4.0 \mathrm{~b}$ & 21.5 & $6.2 \mathrm{a}$ & $1.8 \mathrm{abc}$ & $10.8 \mathrm{bc}$ & $3.0 \mathrm{bcd}$ & $18.7 \mathrm{a}$ & $2.8 \mathrm{~b}$ & $9.5 \mathrm{a}$ & $61.7 \mathrm{a}$ & $17.5 \mathrm{c}$ & $34.0 \mathrm{ab}$ \\
\hline F3B & 36.8 & 37.7 & $8.3 \mathrm{a}$ & 21.2 & $4.1 \mathrm{bc}$ & $1.1 \mathrm{abc}$ & $10.2 \mathrm{bc}$ & $3.7 \mathrm{bcd}$ & $14.3 \mathrm{~b}$ & $5.8 \mathrm{ab}$ & $10.8 \mathrm{a}$ & $54.1 \mathrm{abc}$ & $24.3 \mathrm{bc}$ & $35.7 \mathrm{a}$ \\
\hline M350 & 32.4 & 39.7 & $6.5 \mathrm{ab}$ & 18.2 & $2.8 \mathrm{bc}$ & $0.5 \mathrm{bc}$ & $8.1 \mathrm{bc}$ & $8.1 \mathrm{a}$ & $16.1 \mathrm{ab}$ & $5.0 \mathrm{ab}$ & $5.7 \mathrm{bcd}$ & $53.7 \mathrm{abc}$ & $19.5 \mathrm{bc}$ & $32.0 \mathrm{abc}$ \\
\hline M360 & 35.4 & 44.7 & $5.5 \mathrm{ab}$ & 16.6 & $2.4 \mathrm{bc}$ & $1.1 \mathrm{abc}$ & $8.8 \mathrm{bc}$ & $5.2 \mathrm{a}$ & $15.9 \mathrm{ab}$ & $4.1 \mathrm{~b}$ & $4.5 \mathrm{~cd}$ & $577 \mathrm{ab}$ & $183 \mathrm{c}$ & $26.3 \mathrm{bc}$ \\
\hline SM4 & 40.1 & 39.4 & $7.9 \mathrm{a}$ & 22.2 & $4.3 \mathrm{~b}$ & $2.2 \mathrm{ab}$ & $17.8 \mathrm{a}$ & $2.2 \mathrm{~cd}$ & $13.8 \mathrm{~b}$ & $7.5 \mathrm{a}$ & $7.9 \mathrm{ab}$ & $56.6 \mathrm{ab}$ & $33.2 \mathrm{a}$ & $32.3 \mathrm{abc}$ \\
\hline SPH & 35.0 & 44.9 & $7.5 \mathrm{a}$ & 20.3 & $3.7 \mathrm{bc}$ & $2.6 \mathrm{a}$ & $13.4 \mathrm{ab}$ & $1.9 \mathrm{~cd}$ & $16.4 \mathrm{ab}$ & $7.9 \mathrm{a}$ & $6.2 \mathrm{bc}$ & $59.5 \mathrm{ab}$ & $28.7 \mathrm{ab}$ & $28.5 \mathrm{abc}$ \\
\hline $\mathrm{Cv} . \overline{\mathrm{X}}$ & 36.9 & 41.5 & 6.8 & 19.8 & 3.5 & 1.5 & 11.2 & 3.5 & $13.5 / 12.5$ & $4.9^{\circ}$ & 6.9 & $53.9 / 56.9$ & 22.3 & 30.3 \\
\hline \multicolumn{15}{|l|}{ Significance } \\
\hline Cv. & ** & ** & ** & $* *$ & ** & *** & ** & ** & NS & *** & ** & NS & ** & ** \\
\hline Medium & NS & NS & * & NS & ** & ** & ** & ** & $* *$ & $* *$ & ** & $* *$ & ** & ** \\
\hline Cv. $\times$ Medium & NS & NS & NS & NS & * & $*$ & $* *$ & $* *$ & NS & $* *$ & $* *$ & NS & $*$ & $*$ \\
\hline
\end{tabular}

${ }^{2} \mathrm{~S}=$ 'Summertime', SD = 'Sun Dance', AP = 'Apple Blossom', RL = ‘Red Lion'.

NS,*,**Nonsignificant or significant at $P=0.05$ or 0.01 , respectively. Mean separation in columns is by Duncan's multiple range test.

Table 3. Effects of planting media on days to market stage, days to first flower opening, total leaf length, and total plant height at flowering, and overall plant quality rating of Swaziland (S and SD)- and Dutch (AB and RL)-grown Hippeastrum."

\begin{tabular}{|c|c|c|c|c|c|c|c|c|c|c|c|c|c|c|c|}
\hline \multirow{3}{*}{$\begin{array}{l}\text { Planting } \\
\text { media }\end{array}$} & \multicolumn{6}{|c|}{ Days to } & \multicolumn{6}{|c|}{ Length $(\mathrm{cm})$} & \multirow{2}{*}{\multicolumn{3}{|c|}{$\begin{array}{c}\text { Plant } \\
\text { quality ratingy }\end{array}$}} \\
\hline & \multicolumn{3}{|c|}{ Market stage } & \multicolumn{3}{|c|}{ First flower opening } & \multicolumn{3}{|c|}{ Total leaves } & \multicolumn{3}{|c|}{ Total plant } & & & \\
\hline & $S+S D$ & $\mathrm{AB}$ & RL & $\overline{S+S D}$ & $\mathrm{AB}$ & $\mathrm{RL}$ & $\mathrm{S}+\mathrm{SD}$ & $A B$ & $\mathrm{RL}$ & $\mathrm{S}$ & SD & $\overline{A B}+R L$ & $\mathrm{~S}+\mathrm{SD}$ & $\mathrm{AB}$ & RL \\
\hline$\overline{\mathrm{NCB}}$ & $17.0 \mathrm{bc}$ & $51.7 \mathrm{a}$ & $63.9 \mathrm{ab}$ & $25.6 \mathrm{a}$ & $68.0 \mathrm{a}$ & $81.4 \mathrm{a}$ & $23.1 \mathrm{~b}$ & $25.4 \mathrm{abc}$ & $25.5 \mathrm{c}$ & $47.0 \mathrm{ab}$ & $56.3 \mathrm{a}$ & $53.8 \mathrm{~b}$ & $3.5 \mathrm{ab}$ & 2.7 & 3.8 \\
\hline NCS & $16.2 \mathrm{c}$ & $47.0 \mathrm{bc}$ & $54.1 \mathrm{c}$ & $23.2 \mathrm{e}$ & $63.9 \mathrm{bcd}$ & $71.9 \mathrm{c}$ & $24.4 \mathrm{~b}$ & $19.1 \mathrm{~cd}$ & $35.4 \mathrm{ab}$ & $41.7 c$ & $52.7 \mathrm{a}$ & $54.9 \mathrm{~b}$ & $3.7 \mathrm{a}$ & 2.9 & 3.7 \\
\hline ASB & $17.8 \mathrm{ab}$ & $48.9 \mathrm{ab}$ & $66.6 \mathrm{a}$ & $25.4 \mathrm{ab}$ & $65.8 \mathrm{abc}$ & $82.4 \mathrm{a}$ & $23.6 \mathrm{~b}$ & $20.8 \mathrm{~cd}$ & $26.7 \mathrm{bc}$ & $47.6 \mathrm{ab}$ & $51.7 \mathrm{a}$ & $56.0 \mathrm{ab}$ & $3.6 \mathrm{a}$ & 3.2 & 3.5 \\
\hline F2 & $18.1 \mathrm{a}$ & $46.7 \mathrm{bc}$ & $59.9 \mathrm{~b}$ & 25.9 a & $63.7 \mathrm{bcd}$ & $75.3 \mathrm{bc}$ & $29.8 \mathrm{a}$ & $18.6 \mathrm{~cd}$ & $35.0 \mathrm{ab}$ & $51.6 \mathrm{a}$ & $55.6 \mathrm{a}$ & $56.8 \mathrm{ab}$ & $3.4 \mathrm{ab}$ & 3.2 & 3.5 \\
\hline F3B & $16.9 \mathrm{bc}$ & $42.9 \mathrm{c}$ & $60.1 \mathrm{~b}$ & $24.3 \mathrm{~cd}$ & $59.3 \mathrm{e}$ & $77.1 \mathrm{ab}$ & $23.2 \mathrm{~b}$ & $29.0 \mathrm{ab}$ & $33.5 \mathrm{abc}$ & $46.4 \mathrm{abc}$ & $54.6 \mathrm{a}$ & $55.0 \mathrm{~b}$ & $3.7 \mathrm{a}$ & 3.0 & 3.8 \\
\hline M350 & $18.1 \mathrm{a}$ & $45.9 \mathrm{bc}$ & $63.9 \mathrm{ab}$ & $25.0 \mathrm{abc}$ & $61.9 \mathrm{de}$ & $79.3 \mathrm{ab}$ & $22.7 \mathrm{~b}$ & $21.8 \mathrm{bcd}$ & $24.8 \mathrm{c}$ & 45.8 bc & $55.3 \mathrm{a}$ & $55.3 \mathrm{ab}$ & $3.5 \mathrm{ab}$ & 3.2 & 3.6 \\
\hline M360 & $17.7 \mathrm{ab}$ & $46.2 \mathrm{bc}$ & $65.8 \mathrm{ab}$ & $24.4 \mathrm{~cd}$ & $63.4 \mathrm{~cd}$ & $81.4 \mathrm{a}$ & $22.7 b$ & $17.2 \mathrm{~d}$ & $24.9 \mathrm{c}$ & $45.9 \mathrm{bc}$ & $53.1 \mathrm{a}$ & $55.1 \mathrm{ab}$ & $3.6 \mathrm{a}$ & 3.2 & 3.6 \\
\hline SM4 & $17.2 \mathrm{ab}$ & $46.2 \mathrm{bc}$ & $61.1 \mathrm{ab}$ & $23.7 \mathrm{de}$ & $62.0 \mathrm{de}$ & $77.9 \mathrm{ab}$ & $25.8 \mathrm{~b}$ & $30.7 \mathrm{a}$ & $36.2 \mathrm{a}$ & $41.3 \mathrm{c}$ & $55.1 \mathrm{a}$ & $59.6 \mathrm{a}$ & $3.7 \mathrm{a}$ & 3.0 & 3.9 \\
\hline SPH_ & $17.5 \mathrm{ab}$ & $49.1 \mathrm{ab}$ & $65.7 \mathrm{ab}$ & $24.6 \mathrm{bcd}$ & $66.8 \mathrm{ab}$ & $81.7 \mathrm{a}$ & $22.8 \mathrm{~b}$ & $23.6 \mathrm{a}-\mathrm{d}$ & $28.5 \mathrm{abc}$ & $47.5 \mathrm{ab}$ & $53.8 \mathrm{a}$ & $55.5 \mathrm{ab}$ & $3.2 \mathrm{~b}$ & 2.8 & 3.4 \\
\hline Cv. $\overline{\mathrm{X}}$ & $18.0 / 16.8$ & 47.2 & 62.3 & $27.0 / 22.4$ & 63.9 & 78.6 & $30.4 / 18.0$ & 19.5 & 30.1 & 46.1 & 54.2 & $61.0 / 50.7$ & $3.8 / 3.7$ & 3.0 & 3.6 \\
\hline \multicolumn{16}{|l|}{ Significance } \\
\hline Cv. & $* *$ & $* *$ & $* *$ & $* *$ & $* *$ & ** & $* *$ & ** & ** & ** & $* *$ & ** & $*$ & $* *$ & ** \\
\hline Medium & $* *$ & $* *$ & $* *$ & $* *$ & $* *$ & $* *$ & $* *$ & $* *$ & $* *$ & $\star *$ & 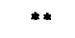 & 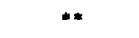 & * & NS & NS \\
\hline \multicolumn{16}{|l|}{ CV. $x$} \\
\hline Medium & NS & $* *$ & ** & NS & $* *$ & $m *$ & NS & ** & $* *$ & * & * & NS & NS & NS & NS \\
\hline
\end{tabular}

'S = 'Summertime”; $\mathrm{SD}=$ 'Sun Dance'; $\mathrm{AB}=$ "Apple Blossom'; RL = 'Red Lion'.

yased on scale where $4=$ excellent, $1=$ poor.

NS,*,**Nonsignificant or significant at $P=0.05$ or 0.01 , respectively. Mean separation in columns is by Duncan's multiple range test.

the nose of the bulb (Fig. 1). Flowering data were recorded when the first flower of the first floral stalk opened fully. On that date, total plant height of the first flower stalk was measured from the rim of the pot to the uppermost petal of the open flower. Total leaf length was measured from the rim of the pot. Overall plant quality ratings $(4=$ excellent, $1=$ poor) were recorded on that same date. This rating is subjective and includes length of the leaves, strength of the floral stalk and leaves, the presence of Stagnospora, and overall flower size.

The root system for Hippeastrum consists of contractile basal roots that produce secondary branch roots (Fig. 2). Initial basal root weight was $36.8,41.5,16.5$, and 16.7 g for 'Summertime', 'Sun Dance', 'Apple Blossom' and 'Red Lion', respectively. From these weights, it was obvious that the Swaziland bulbs had retained more live roots than the Dutch-grown bulbs (Table 2). This difference may be due either to the cultivars or the environment; the Swaziland bulbs were grown outdoors while the Dutch bulbs were grown in greenhouses. Preserving the old basal roots is an important aspect for Hippeastrum forcing and the bulb growers and exporters must protect these roots as much as possible. Also, while there are many inherent cultivar differences (Vijverberg, 1980, 1981), plant breeders should select for a persistent root system.

After the last flower of the first floral stalk opened, the root systems of the bulbs were carefully washed in tap water until free of the planting medium. The basal plate with the roots were cut on 8 and 14 Nov. for 'Sun Dance' and 'Summertime', respectively, 25 Jan. for 'Apple Blossom', and 27 Feb. for 'Red Lion', and stored in plastic bags at 2C. As soon as all the root and basal plate collection of the entire cultivar was completed, roots were subsequently cut from the basal plate. They were classified as old or new basal roots and new secondary roots, and weighed to the nearest $10 \mathrm{mg}$.

When evaluating these data (Tables 2 and 3 ), it is important to keep in mind that the major use for Hippeastrum in North America is as a potted plant that will be first forced and then maintained for flowering in sub- sequent years by the consumer (De Hertogh, 1989).

Swaziland-grown cultivars reached the market and flowering stages of development in fewer days than Dutch-grown cultivars (Table 3). 'Sun Dance' reached both stages earlier than 'Summertime', which agrees with earlier forcing trials (De Hertogh, 1989). 'Apple Blossom' reached both stages in fewer days than 'Red Lion', which is in agreement with results of Vijverberg $(1980,1981)$. The transition period from market stage to flowering was 6 days for 'Sun Dance', 9 days for 'Summertime', and 16 days for 'Apple Blossom' and 'Red Lion'. These data provide an indication of the potential days available for market distribution.

Although the various planting media produced statistically significant differences in the days to reach market and flowering stages for Swaziland cultivars, the range was quite small and commercially not important (Table 3). Because Dutch-grown bulbs took longer to force, there were significant treatment differences and the two Dutch cultivars did not respond similarly to the different media. 


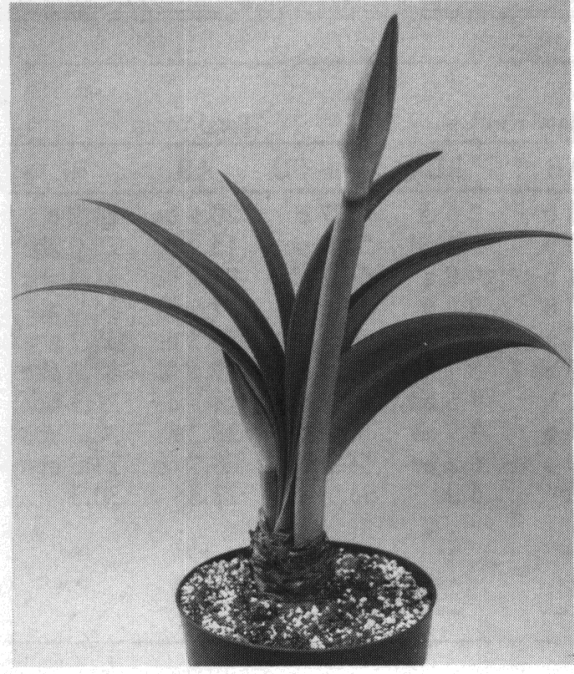

Fig. 1. Example of potted Hippeastrum plant at optimal market stage of floral and leaf development.

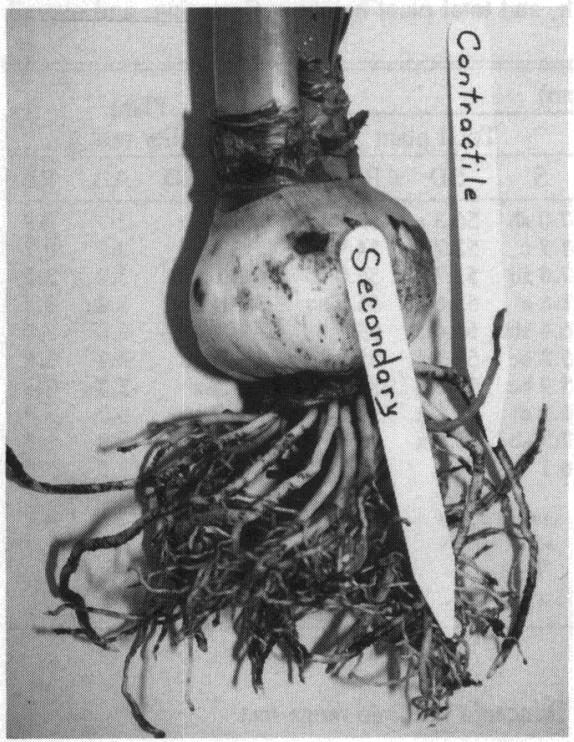

Fig. 2. Example of well-rooted 'Sun Dance' Hippeastrum in Sunshine Mix no. 4. The contractile and secondary roots are identified.

'Apple Blossom' planted in F3B were the quickest to flower, while those planted in the NCR were the slowest. In contrast, 'Red Lion' planted in the NCS were the quickest, while those in NCB, ASB, M360, and SPH were the slowest. Thus, there was no obvious best mix for all the cultivars as far as days to flower was concerned.

Two very important factors in determining plant quality of potted Hippeastrum are the presence and total length of the leaves and total plant height. Ideally, a forced plant should have leaves $>50 \%$ of the total plant height, which should be $\approx 40$ to $50 \mathrm{~cm}$ at flowering. 'Summertime' and 'Sun Dance' produced significantly longer leaves in F2 than in other media (Table 3). 'Summertime', however, had significantly longer leaves than 'Sun Dance'. In contrast to previous reports (Vijverberg, 1980, 1981) that the leaves of 'Apple Blossom' and 'Red Lion' should have been of equal length, our results (Table 3) indicated differences for the two cultivars. This difference could be a production year or a postharvest storage treatment effect. We have observed this difference in other trials. The planting media significantly affected the leaf length of both cultivars (Table 3). SM4, F3B, and SPH led to the production of the longest leaves for both Dutch cultivars. The tallest plants were 'Apple Blossom' followed by 'Sun Dance', 'Red Lion', and then 'Summertime', with the latter two being in the desired total plant height range $(<50 \mathrm{~cm})$ for potted plants. Although there were statistically significant differences in heights, the effects of the various planting media were variable, especially from a commercial viewpoint. For example, the shortest plants of 'Summertime' grew in SM4, but so did the tallest plants of 'Apple Blossom' and 'Red Lion'. With 'Sun Dance' there was no difference.

The effects of the planting medium on overall plant quality were minimal (Table 3). 'Summertime', 'Sun Dance', and 'Red Lion' were highly acceptable as potted plants. 'Apple Blossom' was only rated "good" as a potted plant because it was tall with short leaves. It appears more desirable for cutflower usage.

Characteristics such as number of floral stalks per bulb and number of flowers per stalk were recorded, but data were not reported because these factors are predisposed by bulb size and cultivar. They were not significantly affected by the media used.

'Apple Blossom' was the only cultivar that lost a significant amount of old basal roots regardless of the planting medium (Table 2). F3B, SM4, and SPH produced the lowest loss of the old basal roots. As a result, 'Apple Blossom' produced significantly more new basal roots than 'Red Lion'. 'Red Lion', however, had a larger basal root system than 'Apple Blossom' and this result agrees with Vijverberg's (1980, 1981) findings. With 'Summertime', F2 induced the most new basal roots, while NCB the fewest. For 'Sun Dance', SPH induced the most new basal roots and NCS the fewest. For 'Apple Blossom' and 'Red Lion', new basal root growth was enhanced by SM4 and M350 and M360, respectively. F2 induced the largest amount of secondary root growth with 'Summertime' and 'Sun Dance', while NCB, NCS, and ASB induced the least amount of root growth. For 'Apple Blossom', the two Sunshine mixes led to the most secondary root growth, while, for 'Red Lion', ASB and two
Fafard mixes were best. F2 induced the largest total root mass for 'Summertime' and 'Sun Dance', but it was not significantly different from six other mixes. The NCSU mixes resulted in significantly less total root weight for all cultivars. For 'Apple Blossom', the largest total root mass was obtained with SM4 and SPH. F2 and M350 resulted in the lowest root mass. 'Red Lion' produced the greatest root mass with $\mathrm{F} 3 \mathrm{~B}$, but the results were similar for six other mixes.

SM4 not only preserved the old basal roots but also promoted growth of new basal roots and secondary roots. It was followed by F2, $\mathrm{SPH}$, then F3B. The media that induced the poorest roots were NCB, NCSH, and ASB.

By evaluating all the flowering criteria (Table 3 ) for potted Hippeastrum as well as the rooting responses (Table 2), FB3 and SM4 resulted in the best plants. They were followed by SPH. F2 produced the tallest plants, which is desirable for cut-flower forcing.

Although a component like sphagnum peat is common to F2, F3B, and SM4, it is not possible to conclude what components constitute the optimal planting medium for Hippeastrum. We believe that particle size is a factor and that this is related to both moisture retention and drainage. It is obvious that further research is needed to elucidate the specific components and their ratios for best growth of Hippeastrum.

\section{Literature Cited}

De Haan, F.A.M. and G.G.M. Van der Valk. 1971. Effect of compaction of physical properties of soil and root growth of ornamental bulbs. Acta Hort. 23:326-332.

De Hertogh, A.A. 1989. Holland bulb forcers guide. 4th ed. Intl. Flower Bulb Ctr., Hillegom, The Netherlands.

Genders, R. 1973. Bulbs, A complete handbook of bulbs, corms and tubers. Robert Hale \& Co., London.

Liberty Hyde Bailey Hortorium. 1976. Hortus third: a concise dictionary of plants cultivated in the United States and Canada. 3rd ed. Macmillan, New York.

Van der Valk, G.G.M. 1971. Influence of short periods of restricted soil aeration on develop ment of tulips. Acta Hort. 23:333-337.

Vijverberg, A.J. 1980. De teelt van Hippeastrum (Amaryllis). Bloembollenteeltinformatie no. 17. Proefstation voor Tuinbouw onder Glas te Naaldwijk, Proefstation voor de Bloemisterij te Aalsmeer, Consulentschappen voor de Tuinbouw te Aalsmeer en Naaldwijk, The Netherlands.

Vijverberg, A.J. 1981. Growing Amaryllis. Grower Guide no. 23, Grower Books, London.

Wiersum, L.K. 1971. Tulip root behaviour and aeration requirements. Acta Hort. 23:318-325.

Zandbergen, F. 1980. Alfabetische lijst van de in Nederland in cultuur zijnde Amaryllis (Hippeastrum) cultivars. Kon. Alg. Ver. Bloembollencultuur. Hillegom, The Netherlands. 